\title{
Origins and rationale of centres for parents and young children together
}

\author{
Miwako Hoshi-Watanabe*, Tullia Musatti†, Sylvie Rayna $₫$ and Michel VandenbroeckI \\ *Nagoya University of Arts, Nagoya, Japan, †Institute of Cognitive Sciences \& Technologies, National Research \\ Council of Italy, Rome, Italy, $\ddagger$ Centre Experice, Université Paris 13, Paris, §Ecole Normale Supérieure, Lyon, France, and \\ IIDepartment of Social Welfare Studies, Ghent University, Ghent, Belgium
}

Correspondence:

Michel Vandenbroeck,

Department of Social Welfare

Studies,

Ghent University,

9000 Ghent,

Belgium

E-mail:

Michel.Vandenbroeck@UGent.be

Keywords: child care planning, child care policy and practice, child welfare, family policy, family social work, parenting/parenthood

Accepted for publication:

November 2012

\begin{abstract}
The range of centres where parents and children come together has mushroomed in different parts of the world, as new social work practices address the emerging non-material needs of parents in changing demographic contexts. In this paper, we explore the origins and modi operandi of these centres in Belgium, France, Italy and Japan. Analysis of previous studies and policy documents reveal diverse political rationales, including addressing declining birth rates, preventing psychosocial problems and social isolation of mothers and promoting social cohesion and equality of educational opportunities. Remarkably, despite the diverse cultural and socio-political contexts and rationales, these centres also share very similar ways of functioning and provide an informal type of social support to parents with young children. As these recently emerged centres are seldom studied, further research is welcomed to explore parents' and professionals' perspectives.
\end{abstract}

\section{INTRODUCTION}

The number of centres where parents and young children are expected to attend together has recently mushroomed across continents - in European countries as well as in Japan and Australia. In contrast with their increasing numbers, reports on their functioning remain scarce in the international literature. The functions that are ascribed to these centres can vary according to the cultural and political framework in which they are created. However, they all share a main feature - the attendance of children and parents together - that contradicts the basic custodial function of all other early childhood services, which combine the care and education of children according to different recipes (Cameron \& Moss 2007) but always in the absence of their parents. Does this contradiction

Manuscript proposed for the Special Edition of Child $\mathbb{E}$ Family Social Work.

Special Edition: Rediscovering Family and Kinship: new directions for social work theory, policy and practice. imply that these centres for children and parents (CCP) together would serve totally different functions and make reference to different political frameworks and objectives? If so, which ones?

This paper explores the rationales that underpin the creation of these centres and the policies by which they are supported in France, Flanders, Italy and Japan. It has its origin in visits that each of us researchers operating in the four countries - made to early childhood services in one or more other countries. During these visits, we became aware that, parallel to traditional early childhood education and care (ECEC) services, in all the countries, another type of service - that is, centres for parents and children together - was flourishing and had similar features. These centres, which can be named differently even within the same country (Ko sodate-shien senta, fidokan and Hiroba in Japan; Lieux d'accueil parentsenfants and Maison Verte in France, Centro per bambini e genitori, Tempo per le famiglie and Spazio Insieme in Italy, Ontmoetingsplaatsen voor kinderen en ouders in Belgium) are organized, operated and financially 
supported differently across sites and countries. However, despite the diversity of organization and practices, these initiatives are all related to the changed conditions in which parents take up their roles in post-industrial societies. They aim at providing parents with some form of immaterial support.

This paper will offer a comparative analysis of the general features of these CCP in these four countries. For each country, we will describe their creation and development, highlight the policies and intentions behind their origin and analyse the similarities and differences among the countries with concern to their organization and practices, and the qualifications of the staff that operate the centres. We will then discuss and critically analyse the rationales that seem to underpin their origin and functioning.

Our analysis is based on official documents and previous studies published on these centres in the four countries (Eme 1993; Neyrand 1995; Andreoli 1996; Mantovani \& Musatti 1996; Mantovani et al. 1999; AA.VV. 2003; Musatti \& Picchio 2005; Rullo \& Musatti 2005; Nakaya 2006; Cambi \& Monini 2008; Shiomi et al. 2008; Shirai \& Okano 2009; Vandenbroeck et al. 2009; Scheu \& Fraioli 2011; Tuchida 2011; Geens \& Vandenbroeck forthcoming).

\section{THE CENTRES FOR CHILDREN AND PARENTS IN THE FOUR COUNTRIES}

In the following, we will present a brief sketch of the development and main features of these centres in the four countries.

In France, centres where children and their parent(s) or other caregivers will come together originate from the private initiative of some psychoanalytic associations without any public support in Paris, as early as the 1970s. First, the Club parents - enfants was created by Institut de Recherche Appliquée pour l'Enfant et le Couple in 1976 in a low-class neighbourhood and, in 1979, the Maison Verte was initiated by Françoise Dolto in a middle-class neighbourhood. They were based on the analysis of social isolation and psychological loneliness experienced by parents and their children in their early years, most of whom were cared for exclusively in a domestic environment with one or two adults (relative and childminder were and still are the most frequent form of child care).

The Maison Verte inspired and still inspires a number of centres which developed during the 1980s with the support of Fondation de France. Although these centres were never associated, they show a set of common features, particularly a psychoanalytic approach (Neyrand 1995). They pursue the twofold goal of children's socialization (before they attend pre-school) and prevention of psychological diseases (mostly in the mother-child relationship) and advocate against social control on the basis of the emancipatory potential of psychoanalysis (Dolto 1981, 1985; Institut de Recherche Appliquée pour l'Enfant et le Couple 1992; This 2007; Malandrin \& Schauder 2009). Starting in 1990, a second generation of services, named Lieux d'accueil parents-enfants (Places for welcoming parents and children), developed in more deprived neighbourhoods by the initiatives of social workers. These centres mostly aimed at establishing community relations (Eme 1993) and received financial and organizational support by municipal agencies, schools and other public agencies.

Since 1996, the Lieux d'accueil parents-enfants receive financial support from the Caisse Nationale d'Allocations Familiales (National Fund for Family Assignments), which supports all child care provision. In order to be funded, the CCP is expected not to provide therapy or learning and to be supervised by an expert. The public support induced the transformation of many services operated by non-governmental organizations (NGOs) into public initiatives. These CCP are considered to belong to the policy domain of parent support and, therefore, they did not network with other traditional ECEC services (crèche or école maternelle).

Also, many institutions, as Centres de la Protection Infantile (Child Protection Centres), provide opportunities for parents and children together (Baudelot \& Rayna, 1997; Feret 2009). Most of the centres are still associative (Leprince 2004) and situated in urban regions, in disadvantaged neighbourhoods and municipalities with more than 5000 inhabitants.

The staff are named accueillant(e) (welcoming persons). No specific training is requested, but those centres inspired by a psychoanalytic approach require the staff to have some psychoanalytic training or experience. Most of the staff combine this work with another professional practice, as an early childhood educator, psychotherapist, social worker (rarely a physician, paediatrician, nurse), or with a part-time nonqualified job (Scheu 2010). They have opportunities for team meetings and supervision meetings. Some staff are provided with specific in-service training by local authorities. In 2008, 850 Lieux d'accueil parentsenfants were registered, of which $38 \%$ municipal (Scheu \& Fraioli 2011).

In Italy, centres addressed to children and parents together were realized in the second half of the $1980 \mathrm{~s}$ 
as a result of a debate raised within the public early childhood education sector. In these years, the service nido, whose educational function was positively valued, covered less than $6 \%$ of children and prioritized the children of working mothers. Professionals, experts and policy-makers felt it important to answer both the socialization needs of children not attending a nido and parents' need to receive support in their parenting function. The idea was to offer a place in which parents and children could share play time outside the home and meet with their peers; the childparent relationship can be renewed, benefiting from new experiences. The initiative was directed at any parent with a young child, with the specific function of preventing social and/or psychological problems in parent-child relationships. Particular attention was paid to mothers' psychological and physical isolation and difficulties in their parental role. The first centre was opened by the Municipal Department of Education in Milan with the financial support of Bernard Van Leer Foundation in 1986. It was named Tempo per le famiglie (Time for families) to underline the specificity of the service, offering parents and children to spend time together out of the home. In the following years, many other municipalities, which already were operating nido services of good quality, opened services for parents and children. Financial support to these initiatives was given only by some regional administrations, such as Emilia-Romagna, Umbria and Tuscany, until 1997, when a national act promoting the rights of childhood and adolescence (Law n. 285/1997) supported their extension. Like all ECEC services for under 3-year-old children, these services mostly named Centri per Bambini e Genitori (CCP) are under the responsibility of local governments. Actually, almost all CCP are provided directly by municipalities, by NGOs or private organizations subsidized by the municipalities and are somehow connected to the other municipal early educational services in the area. Only recent regional laws have regulated these services and defined their aims; however, in 2010, an interregional committee included the centres among the social educational services for young children.

The staff consists of professionals with training in education (mostly previous nido or scuola dell'infanzia educators) and are supervised by the pedagogical coordinator who is concerned by the other ECEC in the area. In most cases, the staff received specific training on themes related to parents' needs and conditions and to work with parents and children together.

Most CCP are directed at 18- to 36-month-old children. Special opportunities for children in the first year of life and their parents are organized also in collaboration with maternity or prenatal counselling services. In 2011, approximately 400 CCP were found, almost exclusively in the Northern and Central regions, the same areas in which nido are more numerous.

In Flanders (Belgium), De Speelbrug (The play bridge) was created in 1995 in Antwerp. It was strongly inspired by the French Maison Verte and was the first centre with an explicit psycho-pedagogical framework where children and parents were welcomed to spend time together. Only more than 10 years later, other centres were created. The example of De Speelbrug was followed in two other cities, Leuven in 2008 and in 2009 Destelbergen, near Ghent, which has since closed. In 2009, three private NGOs operating in the field of parent support organizations opened Ontmoetingsplaatsen voor kinderen en ouders (Meeting Places for Children and Parents) in more deprived areas in the cities of Genk, Antwerp and Ghent with structural funding from local governments specifically for organizing these services. Other CCP are self-supportive, have temporary funding (De Speelbrug) or are NGOs funded to organize parent support, but not specifically for Meeting Places. Neither of them have structural connections to child care provisions or pre-schools.

In Brussels, in 2008, the Vlaamse Gemeenschapscommissie (VGC) and the local minister commissioned a study on parents' need for support. This study was set up in parallel with a discussion group of policymakers, researchers and practitioners and revealed a largely shared need for opportunities for children to play together as well as for parents to meet and exchange experiences. As a result, the political decision was taken to fund Meeting Places for Children and Parents in Brussels (Vandenbroeck et al. 2009). The Italian Centri per Bambini e Genitori largely inspired the purposes and functioning of the Brussels meeting places. The first, named Baboes, was opened in May 2009 by an NGO especially created with the support of the VGC: during its first year, it reached very diverse populations (more than 20 languages spoken) (Geens \& Vandenbroeck forthcoming) and has structural links with child care centres in the neighbourhood. A second centre in Brussels opened in 2011. In the same period, the municipal government of Antwerp decided to open three centres. The main rationale for this was the shortage of places in traditional child care centres and the idea that unemployed parents could be directed towards the new services, liberating places in the child care centres for 
working parents. Other informal, disparate initiatives exist, where local mothers take initiatives to meet; some are more organized than others. A network of meeting places (Vlaams Netwerk Ontmoetingsplaatsen voor kinderen en ouders) was formed with two main goals: (i) advocacy of Flemish authorities' recognition of and provision of structural funding to Meeting Places for Children and Parents and (ii) to exchange experiences and learn from each other.

Despite the competent minister acknowledging the value of these initiatives (Vandeurzen 2010), no regulations were created to recognize and support them. In the past few years, however, the governmental agency Kind en Gezin (Child and Family, the agency responsible for the funding of child care and parent support) insisted on taking structural measures to support them and, in 2011, developed a strategic plan to fundamentally rethink preventative health care and transform infant consultation schemes into Huizen van het Kind ('Children's Houses', partly inspired by the Swedish 'Family Centres'), aiming at a more comprehensive approach to families with young children. The strategic plan comprises the functions of the Meeting Places for Children and Parents in the former infant consultation schemes, starting with three pilot projects and with a plan to implement the new services in all municipalities in the following years, with the aim of facilitating informal social support for all parents who wish to make use of it (Vandeurzen 2011).

The staff of Maison Verte-like CCP are volunteers; some are psychoanalytical therapists in other settings. Brussels centres have professional, paid staff, yet not necessarily recruited among child care professionals, while Antwerp personnel are paid by the same municipal authority responsible for early childhood education. In these centres, personnel had specific training provided by training centres which specialize in early childhood education. In future meeting places created as part of preventive health care (Children's Houses), a large proportion of the staff will be volunteers.

In Japan, CCP together, which are named $K_{O}$ sodate-shien senta (Child care support centres), were created and still are inscribed within the framework of policies for supporting parents in children's upbringing. Since the 1950 s, parents have been able to receive some kind of support (children's health diagnosis, consultations or information on children's care and education, play areas in public healthcare centres). Public children's centres have helped mothers organize clubs; some daycare centres opened their playgrounds to parents and children of local areas for several hours a week, and also offered temporary care in emergency situations. In 1989, the decrease in birth rate became a national issue, and the Ministry of Health, Labor and Welfare implemented new policies in order to address the continuous accelerated decline of birth rates (2003: 1.32, 2004: 1.29, 2005: 1.25). Non-working mothers' psychological and social isolation was considered to be one of the reasons for the birth decrease and some municipalities recognized the need of providing a place where mothers could play with their children as well as receive information and counselling about the child's care and upbringing. In 1992, the city of Musashino in the Tokyo area, after consultation among public authorities, residents, nursery teachers and researchers, opened the first place for children and parents. In 1994, the Ministry of Health, Labour and Welfare asked daycare centres' staff to organize actions directed at isolated full-time mothers, and, in the following years, implemented a series of programs for increasing daycare centres and providing support to mothers. In the Child Welfare Act of 1997, which regulates early childhood services, child care support work is defined as 'work that provides centres where infants or toddlers and their parents can interact. It also provides consultation, information, advice and support about child care'.

From 2000 on, neo-liberal policies caused a sharp increase in economic and social inequality (Organisation for Economic Co-operation and Development 2011). The number of needy families and families raising children in quite bad conditions increased and child care support actions had to meet a wide range of problems, including child abuse. In order to expand the municipal care system, the government favoured the participation of private organizations and local groups in daycare provision by lowering the standards and costs of daycare centres. They were also requested to provide parents with child care support. In 2003, the declared objective of child care support policies changed from 'cop[ing] with fewer numbers of children' into 'nurtur[ing] the next generation' and the government stated that, in 2009 , Ko sodate-shien senta should become 'as many as the numbers of secondary schools'. In 2007, the Ministry of Health, Labor and Welfare's Nursery Childcare Guidelines stated that these centres are aimed at preventing or reducing mothers' distress by relieving their feelings of isolation and anxiety through local community support, such as providing opportunities to interact with other mothers, intervention from staff able to listen or to give advice, activities for mothers (such as body care programmes and lectures), counselling 
and information about child care and parenting. Somehow, CCP are expected to substitute the old local community as a place where inhabitants interact, get information and advice and help each other. In 2009, the creation of CCP became a national key policy and providing parent support was considered a compulsory mission for municipal daycare centres. This corresponds to four functions, which were defined in the Nursery Childcare Guidelines: counselling in child care, opening centres for parents and children (usually providing a play area), providing a place to do activities together and promoting their interaction, providing information about child care facilities in the region. Additionally, it addresses the need for collaboration and cooperation among organizations for children's protection. Ko sodateshien senta organized by municipalities inside daycare centres also have the specific function of primary prevention of social or psychological risks.

The centres are directly implemented by municipalities or by private initiatives, with the financial support of prefectures and municipalities varying according to geographical areas. Most were initially funded by the national government, after which financial responsibility was transferred to the municipalities.

In 2010, the number of Ko sodate-shien senta rose to 5521. They are classified into three types according to their budgets, staff qualifications, organization and functions: (i) Ko sodate-shien senta (Child care support centres) are the most numerous (3201 in 2010). They are predominantly operated by and located in daycare centres or other previously existing public facilities (public centres or city halls) and open for more than 5 days per week and for more than 5 hours per day. They provide places for parents and children to play and professional support through counselling, information and lectures. They cooperate with other groups and outreach activities in the local community. (ii) fidokan (children's centres or play facilities for children from 0 to 18) are less numerous (355 in 2010) and serve the same functions. (iii) Hiroba (plaza) (1965 in 2010) are operated by various bodies (non-profit organizations or mothers' associations) at various locations and open for more than 3 days per week. Most of them provide only a meeting place for parents and children, and promote mutual exchange among parents.

Ko sodate-shien and fido-kan are operated by at least one educator or a nurse, while there are no requirements for staff qualifications in Hiroba. The majority of staff, however, are paid professionals with training in education and experience in daycare centres. They are often assisted by untrained volunteers without qualifications. Most can access in-service training provided by the municipalities.

\section{A COMPARATIVE ANALYSIS OF CENTRES FOR CHILDREN AND PARENTS IN THE FOUR COUNTRIES}

Comparative analysis of the evolution of CCP in the four countries shows that it followed similar pathways. In all four countries, the initiatives for creating the centres came from professionals, who were already involved, although from different perspectives, with young children and their parents. Psychotherapists and, later, social workers created these centres in France; in Japan and Italy, the creators were professionals, coordinators and researchers in early childhood education; in Belgium, psychotherapists, early childhood professionals and social researchers took responsibility for them. Beyond these differences, it is unquestionable that in all these countries, CCP have been progressively institutionalized. One of the most relevant consequences of the institutionalizing process is the increasing presence of professional staff. However, the different professional status of the first creators had important consequences for the policies of the local and national agencies. While in Italy and Japan, the debate, planning and implementation of CCP developed within the early childhood education sector or in close connection to it, in France, they remained within the context of professional psychoanalytic associations until they were reinvented with different features by associations and agencies of the social sector, and - only later - officially included in the national governance of the early childhood sector, although within the policies of parent support. In all four countries, CCP were first supported by local governments and only later by higher levels of governing authorities, as they became a public concern only during the last decade of the millennium. In our view, this highlights the important functions of local communities in responding to the changing needs of their population. It is indeed remarkable to notice that despite the diverse historical and cultural foundations - the organization and functioning of CCP in the four countries show substantial commonalities.

All of them are organized in more informal ways, in comparison to traditional ECEC services. Most of them have a part-time schedule opening only some half-days per week, do not follow rigid access procedures and do not charge any fees, or require only a 
small fee from parents. Moreover, most of them are hosted in premises belonging to other services, mainly daycare centres in Italy and Japan, toy libraries and meeting points for childminders in France or municipal halls in France and Japan. In our view, these informal features can be ascribed to the essential nature of these centres. Like traditional child care provisions, the aim is to support parents, mostly mothers, in facing the structural, economic and cultural changes that modernization has introduced into family structure and life. Yet, unlike previous provisions, they are not aimed at responding to parents' material needs in caring and educating young children by providing their temporary custody during mothers' working hours. Rather, the new facilities have been directed at satisfying parents' psychological and social needs in caring for their young child. These needs are nonmaterial as well as most often not clearly expressed. This twofold dimension, immateriality and indefiniteness, shapes also the answer given to parents' needs as most of CCP would neither provide parents with a regular and clear performance nor request a major engagement from them. Beyond the different approaches that inspire practices in the centres, all of them mostly offer the opportunities of a social experience, with professionals, other parents and other children.

\section{THE ANALYSIS OF RATIONALES UNDERPINNING CENTRES FOR CHILDREN AND PARENTS}

The rationales and the goals of the CCP in the four countries show diverse, yet overlapping elements. Later, we try to disentangle these elements and point to tensions that seem to exist between them. It should be noted, however, that the rationales described (as based primarily on policy reports) may differ from the rationales declared by the first local creators of the centres and/or the rationales the staff use for legitimating their work, and may or may not be connected to the reasons why parents make use of CCP.

\section{Demographic reasons}

In Japan, the declining birth rate was one of the major incidences that brought policy-makers to support the creation of Ko sodate-shien senta, in the hope that they could address mothers' social isolation, which was considered one of the causes of birth decrease. In Italy, where birth decline has corresponded to a decrease in the number of siblings in the family, declining birth rates were mentioned as a component of CCP rationale, though with a major focus on their consequences for children's experiences and need to have social contacts with peers. It is probably not a coincidence that these initiatives (as well as others that can be framed as parent support) emerged in times of declining birth rates. It can be argued that declining birth rates make children not only more scarce (and therefore more valuable) but also more planned, desired and precious. This means that parents may have higher expectations for their children's future, in terms of both achievement and happiness, and that states may be more inclined to take initiatives that support these parental ambitions. It can also be argued that in this context, states took a 'parenting turn': focusing more on parenting behaviours (Martin, in press) and, in so doing, raising the pressure that is on parents' shoulders. The increasing feeling of responsibility together with an increasing feeling of loneliness as a parent may then develop into an unsustainable psychological burden, hence the need of sharing experiences among peers.

\section{Insufficient child care provision}

In all four countries, CCP are considered a means to supplement shortages in the availability of traditional child care provision. Actually, in all four countries, even when the centres are addressed to parents and children aged up to 6 , they are attended mostly by children aged under 3 years, that is in the developmental period in which shortage of places in ECEC centres is higher and large parts of the youngest population are cared for at home or in another domestic environment. However, Japanese and Italian surveys show that centres for children and parents serve different populations - unemployed vs. working mothers, families from majorities vs. those from minorities, middle vs. working class; moreover, in many French and Italian centres, an increasing number of grandparents and childminders are observed to accompany the child. Although further research is needed to better understand whether parents consider CCP together a 'second choice' to child care centres and, most importantly, which cultural or organizational processes (opening schedule, location, access procedures, etc.) orient families' use of the centres, we can acknowledge that it implies something more than simply surrogating child care centres and suggests some major concerns about the experience provided to children at home and the adults' capacity to cope with it. 
We can also comment that when the creation of CCP is conceptualized as a means to surrogate for child care, one could expect that they share an educational function aiming at children's holistic development. Although a trend in this direction can be seen in the choice of employing staff with training in early childhood education, few clear orientations towards this educational perspective have appeared so far with some notable exceptions, such as the mission statement of the network of Flemish Ontmoetingsplaatsen voor kinderen en ouders or the statements included in many Italian municipal regulations of the early childhood sector.

\section{Socialization}

The concern for children's experience is expressed in terms of their need for 'socialisation' that, in all countries, is mentioned as one of the more salient rationales for CCP. However, a closer look reveals that socialization may mean very different things in different contexts, for example:

- Adaptation to the prevailing societal norms (e.g. preparation for the école maternelle in France and Italy)

- Opportunities to play with other children and benefit from relationships with peers (explicit in France, Italy and Flanders)

- Experiencing the separation of mother and child. This seems to be the case in some Italian experiences and is prominent in the French and Belgian Maison Verte-like centres, in which separation is considered to be difficult and potentially problematic from a psychoanalytical point of view. In this context, it is very often (implicitly) a gendered theme: it is about the mother, rarely the father.

Furthermore, Japanese and Italian CCP as well as many French and Flemish ones express their intent of taking care also of parents' 'socialisation' by providing a social context in which parents and other caregivers can meet together and benefit from their mutual observation and interaction. Actually, all studies on the representations of both professionals and parents attending CCP in France (Neyrand 1995; Scheu \& Fraioli 2011), in Italy (Musatti \& Picchio 2005; Musatti et al. 2009) and in Belgium (Geens \& Vandenbroeck forthcoming) reported that the opportunity to meet and discuss with persons who share the experience of parenting with a young child is an important component of parents' satisfaction with the CCP.

\section{Parent support}

In all countries, CCP are considered to be - in one way or another - forms of support for parents. Again, however, exactly what such parent support may be is divergent on different aspects.

Some projects, such as those struggling against child abuse in Japan, particularly address parents' problems and responsibilities as first educators. As many scholars have argued, stress on the importance of parenting responsibilities has historically always been accompanied by mistrust of parents' capabilities to take up these responsibilities (Cunningham 1995; Gillies 2005; Featherstone 2006). This perspective may coincide with the expert function of the staff: expert in giving information to parents in Japan, expert in listening to the unconscious in France. This perspective, which is visible through the rationale of many centres, may convey a residual approach to CCP: parents are the first and sole responsible agents, but if a risk of failure is perceived, communities or the state should step in to help. In contrast to this view, many CCP in France and in Italy stress the importance of valorizing and empowering parents' competences. This contradiction seems to be inherent to the rationale of most actions of parent support as its meaning and practice often oscillate from actual supportive to controlling issues of parents and their parenting (Neyrand 2011).

In all countries, the risks associated with mothers' social isolation (or with intensive mothering) are mentioned as a core component of the rationale. Some projects focus less on parental shortcomings, but point at problems associated with the contexts in which parents live and pay more attention to shared responsibilities between parents and the public domain. This approach stresses the importance of meeting and communication between parents inside and outside the centre as a support source and may be more often associated with the role of staff as conveyors (animateurs), hosts or facilitators, rather than their having the educational or psychological expertise deemed necessary to advise parents on their parenting tasks. Actually, the relevance of formal and informal social support in problematic situations where relations between parents and their children are threatened is advocated by several authors (Hardy \& Darlington 2008; Walker 2010; Winkworth et al. 2010). It has been argued that the value of informal and more formal supportive contacts is not restricted to vulnerable families and that mutual informal support between parents can be a particularly important 
resource for them: 'all parents can benefit from exposure to other worldviews, ways of parenting, attitudes, and cultures' (Fram 2005, pp. 515).

The different meanings of the popular term 'prevention' correspond to these different understandings of parental support. Although the term is frequently used in relation to CCP, it is often unclear what should be prevented. In some instances, we have some indications (child abuse in Japan, psychological or social problems in France, Japan and Italy - even if it is not always clear what is meant by these problems). However, the use of the term prevention refers explicitly to goals regarding the future of the parent or more probably - of the child. This may be problematic because the goals (the things that need to be prevented) may be defined by experts rather than parents, and because the focus of prevention lies in an imagined future, rather than in what actually takes place in the here and now. The focus or goal of what is to be avoided or prevented may be in tension with attempts to describe rationale of CCP in positive terms, such as their offering a space in which the child-parent relationship can be renewed while at the same time both benefit from new experiences outside the home (Mantovani \& Musatti 1996).

\section{Community work}

Rationale of CCP sometimes makes explicit references to social work, such as community building and taking care of relationships among citizens and between citizens and public institutions. This is the case for the 'second generation' of centres in France and can be seen in the Japanese guidelines; it is also the source of much discourse on centres in Italy. In the Belgian experience, in Brussels, explicit reference is made to the diverse (and multicultural) contexts of present-day cities. It is noteworthy that, although the presence of immigrant families does not seem to be very frequent in some CCP, the access of ethnic minorities and families living in difficult conditions seem to be a major concern of all CCP in the four countries. From this perspective, these centres should contribute to the construction of a Gemeinschaft, i.e. a space that is intermediate between the public and the private domains and productive of social cohesion, links of solidarity and sense of belonging (Eme 1993; Musatti \& Picchio 2005). This concern for social cohesion is not to be reduced to striving for consensual approaches about parenting, but on the contrary wishes to explore relations in contexts of diversity (Novy et al. 2012). This perspective implies that the aims and goals of CCP reach further than the individual benefits for parents and children and address the neighbourhood - the city - by 'promoting interaction among community members and trying to build an environment supporting child care throughout the region by intergenerational cooperation', as stated by Japanese guidelines. As Winkworth et al. (2010) stressed, universal provisions such as these centres can play a crucial role in bringing families and support provision closer to each other by approaching families in non-stigmatizing ways. Actions in this perspective include networking between CCP and daycare provisions, linking families and services and supporting the creation of social links among parents outside the centre.

\section{CONCLUSION}

Over the past decades, new types of social work practices that address families' needs in the context of dramatic changes in family structure, relationships and daily life have emerged. In particular, in the past 30 to 40 years, earlier in France and Italy and somewhat later in Japan and Belgium, centres were created where parents and children under 3 years could attend together. Despite the increase in such services, very little descriptions or analysis are to be found in the international literature. These centres seem to represent the societal acknowledgement that processes of social and cultural change have introduced important transformations also in the conditions of practising the parental role, particularly at an early age of children. Independently of the rationales that accompanied their creation and expansion in the four countries considered, and the different mixture of concerns that characterize them, such as the struggle against birth decrease, the prevention of social or psychological diseases and the promotion of social cohesion and equal opportunities in education, our analysis has shown that all CCP provide an informal type of social support to parents with young children while addressing family functioning in structural context. Although evidence of their effectiveness in reaching some of their ambitious aims is still to be provided, CCP can be reckoned as an important social observatory where it is possible to analyse, understand, and participate in the complexity and diversity of children's upbringing in our societies. It is clear that more studies are needed to deepen the comparative perspective, to take into account parents' and professionals' perspectives on the meaning of these centres and to assess their impact. 


\section{REFERENCES}

AA.VV. (2003) I servizi per genitori e piccolissimi [Services for parents and babies]. GIFT, settembre, 9-72.

Andreoli, S. (1996) Introduzione: itinerari, tappe e incontri sulla strada di nuovi servizi per bambini e genitori [Introduction: on the way to new services for children and parents]. GIFT, maggio, 3-13.

Baudelot, O. \& Rayna, S. (1997) Les bébés et la culture [Babies and Culture]. INRP, Paris.

Cambi, I. \& Monini, T. (eds) (2008) I Centri per Bambini e Genitori in Emilia-Romagna. Analisi organizzativa e riflessioni [Centres for Children and Parents in Emilia-Romagna]. Edizioni Junior, Bergamo.

Cameron, C. \& Moss, P. (2007) Care Work in Europe. Current Understandings and Future Directions. Routledge, London.

Cunningham, H. (1995) Children and Childhood in Western Society since 1500. Longman, London, New York.

Dolto, F. (1981) La Boutique verte: histoire d'un lieu de rencontres et d'échanges entre adultes et enfants. In: Enfants en souffrance [Children in distress] (eds F. Dolto, D. Rapoport \& B. This), pp. 137-156. Stock, Paris.

Dolto, F. (1985) La cause des enfants [Children's perspective]. Robert Laffont, Paris.

Eme, B. (1993) Des structures intermédiaires en émergence, les lieux d'accueil enfants parents de quartier [Intermediary services for emergency: meeting places for children and parents in the neighbourhood]. CRIDA/CDC, Fondation de France, FAS, Paris.

Featherstone, B. (2006) Rethinking family support in the current policy context. British fournal of Social Work, 36, 5-19.

Feret, G. (2009) Jeu et soutien à la parentalité [Play and parent support]. In: Pour un accueil de qualité de la petite enfance, quell curriculum? (eds S. Rayna, C. Bouve \& P. Moisset), pp. 311325. Erès, Toulouse.

Fram, M.S. (2005) 'It's just not all teenage moms': diversity, support, and relationship in family services. The American fournal of Orthopsychiatry, 75, 507-517.

Geens, N. \& Vandenbroeck, M. (forthcoming) Early Childhood Education and Care as a space for social support in urban contexts of diversity. European Early Childhood Education Research fournal, 21.

Gillies, V. (2005) Meeting parents' needs? Discourses of 'support' and 'inclusions' in family policy. Critical Social Policy, 25, 70-90.

Hardy, F. \& Darlington, Y. (2008) What parents value from formal support services in the context of identified child abuse. Child E Family Social Work, 13, 252-261.

Institut de Recherche Appliquée pour l'Enfant et le Couple (1992) Entrez donc, les psychanalystes accueillent [Come in! You will be welcomed by psychoanalysts]. Editions ESF, Paris.

Leprince, F. (2004) L'accueil des jeunes enfants en France: état des lieux et pistes d'amélioration [Child care in France: state of the art and ways forward]. Haut Conseil de la Population et de la Famille, Paris.
Malandrin, M.H. \& Schauder, C. (2009) F. Dolto, une psychanalyste dans la cité. L'aventure de la Maison Verte [F. Dolto, a psychoanalyst in the city]. Gallimard, Paris.

Mantovani, S. \& Musatti, T. (1996) New educational provisions for young children in Italy. European fournal of Psychology of Education, 11, 119-128.

Mantovani, S., Andreoli, S., Cambi, I., Di Pasquale, G., Maselli, M. \& Monini, T. (1999) Bambini e adulti insieme. Un itinerario di formazione [Children and adults together: a training kit]. Edizioni Junior, Bergamo.

Martin, C. (in press). The invention of a parenting policy in the French context: elements for a policy tracing. In: Sustainability and Transformation in European Social Policy (eds J.G. Ferrer \& I.M. Paya). Peter Lang, Oxford.

Musatti, T. \& Picchio, M. (2005) Un luogo per bambini e genitori nella città [A place for children and parents in the city]. Il Mulino, Bologna.

Musatti, T., Picchio, M. \& Scopelliti, M. (2009) Parents' perception of their toddler's needs for socialization. 19th EECERA Conference, Strasbourg 26-29 August 2009.

Nakaya, N. (2006) Chiiki kosodate shien sesakuno hensen to kadai [Change and aims of policies of support for child rearing]. Fournal of Social Security, 42 (3), 165-173.

Neyrand, G. (1995) Sur les pas de la Maison Verte [On the Path of Maison Verte]. Syros, Paris.

Neyrand, G. (2011) Soutenir et controler les parents. Le dispositif de parentalité. Erès, Toulouse.

Novy, A., Coimbra Swiatek, D. \& Moulaert, F. (2012) Social cohesion: a conceptual and political elucidation. Urban Studies, 49 (9), 1873-1889.

Organisation for Economic Co-operation and Development (2011) Divided We Stand. Organisation for Economic Co-operation and Development, Paris.

Rullo, G. \& Musatti, T. (2005) Mothering young children: child care, stress and social life. European fournal of Psychology of Education, XX, 107-119.

Scheu, H. (2010) Lieux d'accueil enfants-parents et coéducation: du côté des accueillants, [Meeting places and co-éducation]. In: Parents-Professionnels. La coeducation en questions (eds S. Rayna, M.N. Rubio \& H. Scheu). Erès, Toulouse.

Scheu, H. \& Fraioli, N. (2011) Lieux d'accueil enfants parents et socialization(s) [Meeting places for children and parents and socialization(s)]. Strasbourg: Le Furet.

Shiomi, T., Sato, H., Ohinata, M., Komiya, N. \& Yamagata, B. (eds) (2008) Kosodate shienno choryu to kadai [History and functions of support of child rearing]. Gyosei, Tokyo.

Shirai, C. \& Okano, A. (eds) (2009) Kosodate shien seido to genba [System and fields of support of child rearing]. Shinsensha, Tokyo.

This, B. (2007) La maison verte. Créer des lieux d'accueil [The Maison verte. Creating meeting places]. Belin, Paris.

Tuchida, M. (2011) Chiiki kosodate shien kyoten shisen toshiteno hoikusho no kino to kanosei [Functions and possibilities of the daycare centre as the core support centre]. Bulletin of Ryukoku University-Faculty of Sociology, 39, 21-31. 
Meeting places for parents and young children M Hoshi-Watanabe et al.

Vandenbroeck, M., Boonaert, T., Van der Mespel, S. \& De Brabandere, K. (2009) Dialogical spaces to reconceptualize parent support in the social investment state. Contemporary Issues in Early Childhood, 10 (1), 66-77.

Vandeurzen, J. (2010) Beleidsbrief Welzijn, Volksgezondheid en Gezin. Beleidsprioriteiten 2010-2011 [Policy brief Welfare, Health and Family]. Brussel: Vlaamse regering.

Vandeurzen, J. (2011) BeleidsbriefWelzijn,Volksgezondheid en Gezin. Beleidsprioriteiten 2012-2013. Brussels: Vlaamse regering.
Walker, L. (2010) 'His mam, my dad, my girlfriend, loads of people used to bring him up': the value of social support for (ex) offender fathers. Child E Family Social Work, 15, 238247.

Winkworth, G., McArthur, M., Layton, M. \& Thompson, L. (2010) Someone to check in on me: social capital, social support and vulnerable parents with very young children in the Australian Capital Territory. Child E Family Social Work, 15, 206-215. 